\title{
Isolation of a novel amylase and lipase-producing Pseudomonas luteola strain: study of amylase production conditions
}

\author{
Lamia Khannous ${ }^{1}$, Mouna Jrad ${ }^{2}$, Mouna Dammak ${ }^{3}$, Ramzi Miladi ${ }^{3}$, Nour Chaaben ${ }^{3}$, Bassem Khemakhem², \\ Néji Gharsallah ${ }^{2}$ and Imen Fendri ${ }^{\text {* }^{*}}$
}

\begin{abstract}
An amylase and lipase producing bacterium (strain C2) was enriched and isolated from soil regularly contaminated with olive washing wastewater in Sfax, Tunisia. Cell was aerobic, mesophilic, Gram-negative, motile, non-sporulating bacterium, capable of growing optimally at $\mathrm{pH} 7$ and $30^{\circ} \mathrm{C}$ and tolerated maximally $10 \%(\mathrm{WN}) \mathrm{NaCl}$. The predominant fatty acids were found to be $C_{18: 1} \omega 7 \mathrm{c}(32.8 \%), C_{16: 1} \omega 7 \mathrm{c}(27.3 \%)$ and $C_{16: 0}(23.1 \%)$. Phylogenetic analysis of the $16 \mathrm{~S}$ rRNA gene revealed that this strain belonging to the genus Pseudomonas. Strain C2 was found to be closely related to Pseudomonas luteola with more than $99 \%$ of similarity. Amylase optimization extraction was carried out using Box Behnken Design (BBD). Its maximal activity was found when the $\mathrm{pH}$ and temperature ranged from 5.5 to 6.5 and from 33 to $37^{\circ} \mathrm{C}$, respectively. Under these conditions, amylase activity was found to be about $9.48 \mathrm{U} / \mathrm{ml}$.
\end{abstract}

Keywords: Pseudomonas luteola, Amylase, Lipase, Box Behnken Design

\section{Introduction}

Pseudomonas species, ubiquitous in soil and water [1,2], are of considerable scientific and technological importance and comprise a taxon of metabolically versatile organisms capable of utilizing a wide range of simple and complex organic compounds [3]. During the last few years, Pseudomonas strains have been increasingly studied with increasing interest because of their importance in the fields of medicine, food technology, environmental microbiology and phytopathology [4]. They are known to be involved in the biodegradation of natural and toxic man-made chemical compounds. In addition, the bacterial genus Pseudomonas is a prolific producer of a number of extracellular enzymes, including lipase and amylase [5].

$\alpha$-amylase (E.C 3.2.1.1) catalyses the hydrolysis of $\alpha$ D- $(1,4)$ glycosidic linkages in starch and related carbohydrates. It is a key enzyme in the production of starch derivatives and also widely used in food, textile, paper,

\footnotetext{
* Correspondence: imen.fendri@yahoo.fr

${ }^{1}$ Faculté des Sciences de Sfax, Unité de recherche Toxicologie- Microbiologie Environnementale et Santé, Université de, Sfax, Tunisia

Full list of author information is available at the end of the article
}

detergent, clinical, pharmaceutical and other industrial fields [6,7].

In the last decades, there has been lots of research on the amylases from animals [8], plants [9] terrestrial bacteria [2] and marine bacteria [6]. Interest in bacterial amylases has increased due to their biotechnological applications [10]. Many microorganisms such as bacteria, yeast, and fungi are known to secrete amylases during their growth on starch substrates, which makes starch derivates available to cells.

In conventional multifactor experiments, optimization of plant extraction is usually carried out by varying a single factor while keeping all other factors fixed at a specific set of conditions. It is not only time-consuming, but also usually incapable of reaching the true optimum due to ignoring the interactions among variables [11]. Response surface designs such as central composite design (CCD) and Box Behnken Design (BBD) are commonly selected for performing optimization studies. Compared to the CCD method, the BBD technique is considered the most suitable for evaluating quadratic response surfaces particularly in cases when predicting the response at the extreme level is not the goal of the model. The BBD technique is a three level design based

\section{Biomed Central}


upon the combination of two-level factorial and incomplete block designs [12,13]. The BBD method employs a spherical design with excellent predictability within the design space and it requires less experiment than the FFD or CCD with the same number of factors [14]. In addition, the BBD technique is rotatable or nearly rotatable regardless of the number of factors under consideration [14].

In our study, a new strain C2 was isolated from soil regularly contaminated with olive washing wastewater and the diversity of their extracellular hydrolytic enzymes (lipase and amylase) was studied. The results showed that stain $\mathrm{C} 2$, which was identified as Pseudomonas luteola, had a high amylase activity. Optimization extraction was carried out using Box Behnken Design (BBD). This amylase showed a high activity, lead to expect a great commercial value and a good prospect for industrial applications.

\section{Materials and methods}

\section{Source of strains and media}

Soil samples were collected in sterile bottles from soil regularly contaminated (for more than 3 years) with olive washing wastewaters in Sfax (Tunisia) and stored in the dark at $4^{\circ} \mathrm{C}$ until use. Ten strains were isolated. Strain C2, was used for further experiments. For this purpose, Luria-Berttani (LB) medium containing $10 \mathrm{~g}$ peptone, $5 \mathrm{~g}$ yeast extracts and $5 \mathrm{~g} \mathrm{NaCl}$ per liter was used. Fifteen grams of agar per liter were added when solid medium was required. The $\mathrm{pH}$ was adjusted to 7.0 with $10 \mathrm{M}$ of $\mathrm{KOH}$ solution. Aliquots of $25 \mathrm{ml}$ were dispensed into flasks and sterilized by autoclaving them at $121^{\circ} \mathrm{C}$ for $20 \mathrm{~min}$.

\section{Isolation of bacteria}

Suspensions of $1 \%(\mathrm{w} / \mathrm{v})$ soil sample from ground contaminated with industrial wastewater were incubated with the medium at $30^{\circ} \mathrm{C}$ under agitation at $180 \mathrm{rpm}$ for 72 hours. The dominant microorganisms of this consortium were isolated by spreading $0.1 \mathrm{ml}$ of tenfold serial solution on Petri dishes containing screening medium agar $[2,15]$. The various colonies were picked, isolated in pure cultures and then stored at $-80^{\circ} \mathrm{C}$. Among the strains isolated, the bacterial colony named strain C2 was used for further experiments.

\section{Strain characterization}

The $\mathrm{pH}$ of the medium was adjusted with $5 \mathrm{M} \mathrm{HCl}$ or $10 \mathrm{M} \mathrm{KOH}$ (in 0.5 -unit steps) to obtain $\mathrm{pH}$ values ranging between 4 and 12 . Various amounts of $\mathrm{NaCl}$ were directly weighed in flasks prior to dispensing a $25 \mathrm{ml}$ medium with the desired $\mathrm{NaCl}$ concentration (range from 0 to $250 \mathrm{~g} / \mathrm{l}$ ). The temperature range for growth was analyzed between 5 and $55^{\circ} \mathrm{C}$ (in $5^{\circ} \mathrm{C}$ intervals).
Microscopes were performed as described by Abdelkafi et al. $[16,17]$. To test the heat resistance, cells grown in a basal medium containing olive oil were exposed to temperatures of 80,90 and $100^{\circ} \mathrm{C}$ for $10 \mathrm{~min}$. The cells were cooled quickly to ambient temperature and inoculated into fresh Luria broth medium, and their growth was recorded after $24 \mathrm{~h}$ incubation at $37^{\circ} \mathrm{C}$ under agitation at $180 \mathrm{rpm}$. The conditions under which sporulation was tested included growth in the absence of a carbon source or in the presence of yeast extract. Growth under anaerobic conditions was determined as described previously $[18,19]$. Gram reaction was determined using the BioMérieux Gram stain Kit according to the manufacturer's instructions. Catalase activity was determined based on bubble production in a $3 \%(\mathrm{v} / \mathrm{v})$ hydrogen-peroxide solution. Oxidase activity was determined by testing the oxidation of $1 \% p$-aminodimethylaniline oxalate. Experiments were performed in duplicate with an inoculum subcultured at least once under the same test conditions. The substrates tested for utilization were injected from pre-sterilized and concentrated stock solutions into flasks containing a $25 \mathrm{ml}$ pre-sterilized medium. The following substrates were used: carbohydrates $(20 \mathrm{mM})$ (glucose, fructose, galactose, maltose and lactose); gelatin, peptone, and yeast extract ( $2 \mathrm{~g} / \mathrm{l})$ and glycerol $(20 \mathrm{mM})$. An increase in the $\mathrm{OD}_{600}$ value obtained with substrate-containing cultures, compared with control tubes lacking substrates, was considered as positive growth. Other phenotypic characteristics were determined using API 20NE and API 50CH kits (BioMérieux, La Balme-Les-Grottes, France), as described by Logan and Berkeley [20]. In addition, the API ZYM gallery (BioMérieux, La Balme-Les-Grottes, France) method was used to determine the extracellular enzymatic activities.

Resistance to antibiotics was determined on MuellerHinton agar (Difco, Beckton Dickinson, Le Pont de Claix, France) using standard antibiotic disks (BioMérieux, Marcy l'Etoile, France). Inhibition diameters were recorded after $24 \mathrm{~h}$ of incubation at $30^{\circ} \mathrm{C}$ under aerobic conditions. Strains were classified as sensitive, not sensitive or intermediately sensitive to the antibiotics tested in the line with the disk manufacturer's instructions. All tests were performed in triplicate.

\section{Analysis of cellular fatty acids}

Fatty acid methyl esters were determined as described by Ben Ali et al. [19].

\section{Sequencing and phylogenetic analysis}

The 16S rRNA gene of strain C2 was amplified by adding $1-\mu \mathrm{L}$ cell culture to a thermocycler microtube containing $5 \mu \mathrm{l}$ of $10 \times \mathrm{Taq}$ buffer, $0.5 \mu \mathrm{l}$ of each $50 \mathrm{nM}$ primers $\mathrm{Fd} 1$ and $\mathrm{Rd} 1,5 \mu \mathrm{l}$ of $25 \mathrm{mM} \mathrm{MgCl} \cdot 6 \mathrm{H}_{2} \mathrm{O}$, 
$0.5 \mu \mathrm{l}$ of $25 \mathrm{mM}$ dNTPs, $0.5 \mu \mathrm{l}$ of Taq polymerase $(5 \mathrm{U} / \mu \mathrm{l})$ and $38 \mu \mathrm{l}$ of sterilized distilled water. The universal primers Fd1 and Rd1 (Fd1, 5' -AGAGTTTGATCCTGGCTCAG-3; Rd1, 5'-AAGGAGGTGATCCAGCC-3') were used to obtain a PCR product with a molecular weight of $\sim 1.5 \mathrm{~kb}$ corresponding to base positions 8 to 1542, based on Escherichia coli numbering of the 16S rRNA [21]. Each sample was placed in a hybrid thermal reactor thermocycler (BIOMetra), denatured by heating for $1 \mathrm{~min}$ at $96^{\circ} \mathrm{C}$ and subjected to 30 cycles for $20 \mathrm{~s}$ at $96^{\circ} \mathrm{C}, 30 \mathrm{~s}$ at $55^{\circ} \mathrm{C}$ and $2 \mathrm{~min}$ at $72^{\circ} \mathrm{C}$. This was followed by a final 5-min elongation step at $72^{\circ} \mathrm{C}$. PCR products were cloned using the pGEM-T-easy cloning kit (Promega) as recommended by the manufacturer. Clone libraries were screened by performing direct PCR amplification on a colony using the vector-specific primers SP6 (5' ${ }^{\prime}$-ATTTAGGTGACACTA TAGAA-3') and T7 (5'-TAATACGACTCACTATAGGG $\left.-3^{\prime}\right)$ and the following reaction conditions: initial 2-min denaturation at $96^{\circ} \mathrm{C}$, then 40 denaturation cycles, annealing and extension for $30 \mathrm{~s}$ at $96^{\circ} \mathrm{C}, 30 \mathrm{~s}$ at $50^{\circ} \mathrm{C}, 2 \mathrm{~min}$ at $72^{\circ} \mathrm{C}$, and a final extension for $5 \mathrm{~min}$ at $72^{\circ} \mathrm{C}$. Plasmids containing inserts of the expected length were isolated using the Wizard Plus SV Minipreps DNA purification system (Promega), as recommended by the manufacturer. Purified plasmids were sent for sequencing to GATC Company (France). Sequence data was imported into the sequence editor BioEdit version 5.0.9 [22]; base calling was examined and a contiguous sequence was obtained. The full sequence was aligned using the RDP Sequence Aligner program [23]. The consensus sequence was adjusted manually to fit the 16S rRNA secondary structure model [21]. A nonredundant BLAST search [24] was performed to identify the closest relatives. Sequences used in the phylogenetic analysis were obtained from the RDP [23] and GenBank databases [25]. Positions of sequence and alignment ambiguities were omitted and pairwise evolutionary distances were calculated using the method of Jukes and Cantor [26]. A dendrogram was constructed using the neighbor-joining method [27]. Confidence in the tree topology was determined using 100-bootstrapped trees [28].

\section{Lipid utilization and lipase activity assay}

To study the ability of the new isolate to grow on lipids, experiments were performed on agar plates with rhodamin $B$ and in liquid cell cultures with and without a lipid carbon source. To analyse the ability of this strain to grow and degrade lipids, filtered olive oil was added to the medium $(2 \%, v / v)$ [29]. Lipase activity was assayed as described by Abdelkafi et al. [30,31].

\section{Amylase activity assay}

The amount of the reducing sugars released by the action of amylases on starch was currently performed at $60^{\circ} \mathrm{C}$ and $\mathrm{pH} 5$ for $10 \mathrm{~min}$ [7]. The reaction mixture contained $0.5 \%(\mathrm{w} / \mathrm{v})$ starch in $25 \mathrm{mM}$ acetate buffer and the enzyme solution in a final volume of $1 \mathrm{ml}$. The concentration of reducing sugar was determined by the DNS method [32]. One unit of amylase was defined as the amount of enzyme, required to produce reducing sugars equivalent to $1 \mu \mathrm{mol}$ glucose/min.

\section{Effect of temperature and $\mathrm{pH}$}

The effect of temperature on the activity of extracellular amylase was performed by its supernatant incubation at different temperatures ranging from 40 to $100^{\circ} \mathrm{C}$. The reaction was performed according to the method of amylase assays described above. The effect of $\mathrm{pH}$ on the activity of amylase was determined at $\mathrm{pH}$ ranging from 4 to 10.5 at $60^{\circ} \mathrm{C}$. The buffers used are: sodium acetate $0.1 \mathrm{M}$ (pH 4-6.5), phosphate $0.1 \mathrm{M}$ (pH 7-9) and glycine- $\mathrm{NaOH} \quad 0.1 \mathrm{M}$ (pH 9-10.5). The activities at optimal temperature and $\mathrm{pH}$ were defined as $100 \%$.

\section{Thermal stability}

Amylases in sodium acetate buffer (50 mM, pH 5.0) were incubated at a temperature range of $50-60^{\circ} \mathrm{C}$ and then samples were withdrawn for enzyme assay at appropriate time intervals. The residual activity was estimated taking original activity as 100\% [7].

\section{pH stability}

Stability of amylases was determined using different buffers such as glycine- $\mathrm{HCl}$ ( $\mathrm{pH} 2.0-3.0)$, sodium acetate ( $\mathrm{pH} 4.0-$ 6.5), sodium phosphate ( $\mathrm{pH} 7.0-8.0$ ), glycine- $\mathrm{NaOH} 0.1 \mathrm{M}$ $(\mathrm{pH} 9-10.5)$ at $50 \mathrm{mM}$ concentration. Amylase was incubated in different buffers for $24 \mathrm{~h}$ at room temperature. The original activity was taken as control (100\%) [7].

\section{Experimental design and data analysis}

The Box Behnken Design (BBD) composite, with three replicates at the central points was employed to fit a second-order polynomial model and to obtain an experimental error. The BBD was applied with three design factors and three levels. The factors are the medium $\mathrm{pH}$ (X1), the temperature (X2) and the time of contact between substrate-enzyme (X3). The coded levels and the natural values of the factors set in this statistical experiment are shown in Table 1. The central values (zero level) chosen for the experimental design were as follows: the $\mathrm{pH}, 7$; the temperature, $37^{\circ} \mathrm{C}$ and the contact time, $24 \mathrm{~h}$. The substrate chosen in this study was the starch.

Amylase activity was selected as the dependent variable. The response variable was fitted by a second-order model in the form of quadratic polynomial equation: 
Table 1 Levels of the variables tested in the BBD designs

\begin{tabular}{lccc}
\hline Variables & \multicolumn{3}{c}{ Range and levels } \\
\cline { 2 - 4 } & $\mathbf{- 1}$ & $\mathbf{0}$ & $\mathbf{1}$ \\
\hline $\mathbf{X}$ 1, pH & 4 & 7 & 10 \\
X2, Temperature $\left({ }^{\circ} \mathrm{C}\right)$ & 30 & 37 & 44 \\
X3, Incubation time $(\mathrm{h})$ & 12 & 24 & 36 \\
\hline
\end{tabular}

$$
y=b_{0}+\sum_{i=1}^{k} b_{i} X_{i}+\sum_{i=1}^{k} b_{i i} X_{i}+\sum_{i}^{i<j} \sum_{j} b_{i j} X_{i} X_{j}
$$

where $\mathrm{y}$ is the response variable to be modeled; $\mathrm{Xi}$, and $\mathrm{Xj}$ the independent variables which influence $\mathrm{y} ; \mathrm{b}_{0}, \mathrm{~b}_{\mathrm{i}}, \mathrm{b}_{\mathrm{ii}}$ and $b_{i j}$ are the offset terms, the ith linear coefficient, the quadratic coefficient and the ijth interaction coefficient, respectively. The actual design used in this work is presented in Table 2. Analysis of variance (ANOVA) was used for graphical analyses of the data to obtain the interaction between the process variables and the responses. The quality of the fit polynomial model was expressed by the coefficient of determination $\mathrm{R}^{2}$, and its statistical significance was checked by the F-test. Model terms were selected or rejected based on the p-value (probability) with 95\% confidence level. Three-dimensional plots and their respective contour plots were obtained based on the effects of the levels of two factors. The experimental design, regression and statistical analysis were performed, by NemrodW ${ }^{\bullet}$ software [33]. The optimum values of selected variables were obtained by using the desirability function available in $\mathrm{NemrodW}^{\odot}$ and also by analyzing the response

Table 2 BBD and response results

\begin{tabular}{lcccc}
\hline Runs & \multicolumn{3}{c}{ Factors } & $\begin{array}{c}\text { Response: amylase } \\
\text { activity (U/ml) }\end{array}$ \\
\cline { 2 - 5 } $\mathbf{X} \mathbf{1}$ & $\mathbf{X 2}$ & $\mathbf{X 3}$ & 9.48 \\
2 & 0 & 0 & 0 & 4.49 \\
3 & 1 & -1 & 0 & 9.14 \\
4 & 0 & 0 & 0 & 1.7 \\
5 & -1 & 0 & 1 & 7.08 \\
6 & -1 & 0 & -1 & 9.42 \\
7 & 0 & 0 & 0 & 1.8 \\
8 & 0 & -1 & 1 & 8.97 \\
9 & 0 & 0 & 0 & 4.48 \\
10 & 0 & 1 & 1 & 5.45 \\
11 & -1 & 0 & -1 & 8 \\
12 & 0 & -1 & -1 & 8.31 \\
13 & -1 & 0 & 1 & 3.65 \\
14 & 0 & 1 & -1 & 8.68 \\
15 & -1 & -1 & 0 & 5.97 \\
\hline
\end{tabular}

surface contour plots. The parameters of the response equations and corresponding analysis on variations were evaluated using Uniform Design Software 2.1 (http://en. softonic.com/s/uniform-design-software-2.1) and MATLAB 6.5 , respectively. The interactive effects of the independent variables on the dependent ones were illustrated by three and two-dimensional contour plots. Finally, two additional experiments were conducted to verify the validity of the statistical experimental strategies.

\section{Results and discussion}

Isolation of bacteria

To isolate different lipid-degrading microorganisms, an enrichment culture method was used as described in Materials and Methods. Based on their morphological characteristics, several strains were isolated. The strain used in this work, named C2, was selected for further characterization. Species belonging to the genus Pseudomonas have been isolated from a variety of natural sources including soil, plants, marine environments, and activated sludge $[34,35]$. The present results extended the range of known ecosystems to include soil contaminated with olive washing wastewater.

\section{Morphology and physiology}

The organism used in this study was a mesophilic strain which was isolated from soil contaminated with wastewater. Cells of strain C2 were Gram-negative, motile and aerobic. Similar characteristics have been described in other Pseudomonas species by $[4,35,36]$. Spores were not observed.

The optimum $\mathrm{pH}$ and temperature values for the growth of this isolate were first determined under aerobic conditions in Erlenmeyer flasks. Growth was observed at temperatures ranging between 20 and $50^{\circ} \mathrm{C}$, and optimum growth occurred at $30^{\circ} \mathrm{C}$, but the isolate did not grow at $56^{\circ} \mathrm{C}$. The $\mathrm{pH}$ range for growth was 5-9, with an optimum at 7 . Growth occurred in the 0 to $10 \%$ $\mathrm{NaCl}$ range. Anaerobic growth does not occur. Catalase and oxidase reactions were positive and negative, respectively. Citrate was used. Gelatine was hydrolyzed. Other characteristics of strain C2 in comparison with those of the closely related species of genus Pseudomonas are given in Table 3 .

\section{Properties of strain C2 in API-ZYM test}

The strain under investigation showed a high rate of enzyme activity for alkaline phosphatase, esterase (C4), esterase lipase (C8), leucine arylamidase, trypsin, acid phosphatase and cystine arylamidase. No activity was detected for $\alpha$-mannosidase and $\alpha$-fucosidase. 
Table 3 Main characteristics of strain C2 and Pseudomonas luteola

\begin{tabular}{|c|c|c|}
\hline Characteristics & Strain C2 & Pseudomonas luteola \\
\hline Gram stain & - & - \\
\hline Catalase & + & + \\
\hline Oxidase & - & - \\
\hline Motility & + & + \\
\hline Colour & nd & + \\
\hline Optimum temperature growth $\left({ }^{\circ} \mathrm{C}\right)$ & 30 & 30 \\
\hline Growth at $40^{\circ} \mathrm{C}$ & + & + \\
\hline Growth with $8 \% \mathrm{NaCl}$ & + & - \\
\hline Optimum pH growth & 7 & 7.2 \\
\hline Denitrification & - & - \\
\hline Gelatinase & + & + \\
\hline Amylase & + & nd \\
\hline \multicolumn{3}{|l|}{ Assimilation of: } \\
\hline Citrate & + & + \\
\hline Malate & + & + \\
\hline Maltose & + & + \\
\hline Mannitol & + & + \\
\hline Mannose & + & + \\
\hline Glucose & - & + \\
\hline
\end{tabular}

+, positive; -, negative; nd, not determined.

\section{Antibiotic susceptibility}

The growth behaviour of the $\mathrm{C} 2$ isolate was studied in the presence of a range of antibiotics. The strain was susceptible to penicillin $(6 \mu \mathrm{g})$, chloramphenicol $(30 \mu \mathrm{g})$, kanamycin (30 IU) and tetracycline (30 IU); and resistant only to erythromycin $(15 \mu \mathrm{g})$.

\section{Fatty acid composition}

The cellular-fatty-acid profiles of strain C2 show the presence of large amounts of saturated and unsatured fatty acids (Table 4). The main fatty acids detected in this strain were $C_{18: 1} \omega 7 \mathrm{c}(32.8 \%), C_{16: 1} \omega 7 \mathrm{c}(27.3 \%)$ and $\mathrm{C}_{16: 0}(23.1 \%)$, which together accounted for $>83 \%$ of the total fatty acids. Similar fatty acid components predominate in other species of the genus Pseudomonas such as Pseudomonas xiamenensis [34]. These results confirming that this strain belongs to the genus Pseudomonas. However, some considerable differences between the fatty acid profiles were detected. For example, $\mathrm{C}_{17: 0}$ cyclo, detected in other Pseudomonas strains such as Pseudomonas simiae CCUG $50988^{\mathrm{T}}$ (11.7\%) [37]. This discrepancy may have resulted from differences between the experimental conditions used, in the growth conditions or the analytical equipment used, for example. Other minor components present
Table 4 Cellular fatty-acid profiles (\%) of Pseudomonas sp. strain C2 in comparison with those of Pseudomonas luteola IAM $13000^{\top}$

\begin{tabular}{lcc}
\hline Fatty acids & Strain C2 & P. luteola \\
\hline $\mathbf{C}_{\mathbf{1 0 : 0}} \mathbf{3 O H}$ & 3.4 & 3.8 \\
$\mathbf{C}_{\mathbf{1 2 : 0}}$ & 5.2 & 6.9 \\
$\mathbf{C}_{\mathbf{1 2 : 0}} \mathbf{2 O H}$ & 3.3 & 3.2 \\
$\mathbf{C}_{\mathbf{1 2 : 0}} \mathbf{3 O H}$ & 2.1 & 3.5 \\
$\mathbf{C}_{\mathbf{1 4 : 0}}$ & 0.8 & 1.0 \\
$\mathrm{C}_{\mathbf{1 6 : 0}}$ & 23.1 & 18 \\
$\mathbf{C}_{\mathbf{1 8 : 0}}$ & 0.4 & 0.2 \\
$\mathbf{C}_{\mathbf{1 9 : 0}} \mathrm{CYCLO} \omega \mathbf{8 c}$ & $\mathrm{ND}$ & 0.3 \\
$\mathbf{C}_{\mathbf{1 6 : 1}} \omega \mathbf{7 C}$ & 27.3 & 23.3 \\
$\mathbf{C}_{\mathbf{1 8 : 1}} \omega \mathbf{7 c}$ & 32.8 & 39.7 \\
\hline
\end{tabular}

ND, not detected.

included $\mathrm{C}_{10: 0} 3-\mathrm{OH}$ (3.4\%), $\mathrm{C}_{12: 0}(5.2 \%), \mathrm{C}_{12: 0} 2-\mathrm{OH}$ (3.3\%), $\mathrm{C}_{12: 0} \quad 3-\mathrm{OH}(2.1 \%), \mathrm{C}_{14: 0}(0.8 \%)$ and $\mathrm{C}_{18: 0}$ $(0.4 \%)$.

\section{Phylogenetic analysis}

To analyze the phylogenetic position of $\mathrm{C} 2$, the $16 \mathrm{~S}$ rRNA gene sequence (comprising 1378 bases) was determined and a phylogenetic tree based on 1247 unambiguous bases was constructed (Figure 1). Phylogenetic analysis showed that strain $\mathrm{C} 2$ is a member of the Gammaproteobacteria. Dendrogram analysis showed that this isolate formed a coherent cluster with species of the genus Pseudomonas. Our isolate was found to be closely related to Pseudomonas luteola, with which it shows more than $99 \%$ similarity between the $16 \mathrm{~S}$ rRNA gene sequences.

\section{Lipid degradation}

Agar plates containing olive oil and rhodamine B have a pinkish colour and an opaque appearance. Lipase production was monitored by irradiating plates with UV light at $350 \mathrm{~nm}$. After $24 \mathrm{~h}$ of incubation, bacterial colonies began to show orange fluorescence; with longer incubation times, orange fluorescent halos were formed around the colonies of lipase producing strains. Strain C2 showed fluorescent halo (data not shown). It has been established that Pseudomonas species can degrade various triacylglycerol $[38,39]$.

\section{Optimization of amylase extraction}

The effect of the temperature and the $\mathrm{pH}$ on the amylase activity in the supernatant was performed by its incubation at different temperatures ranging from 40 to $100^{\circ} \mathrm{C}$ and at $\mathrm{pH}$ ranging from 4 to 10.5 . The highest amylase activity was given at $60^{\circ} \mathrm{C}$ and at $\mathrm{pH} 5$ (data 


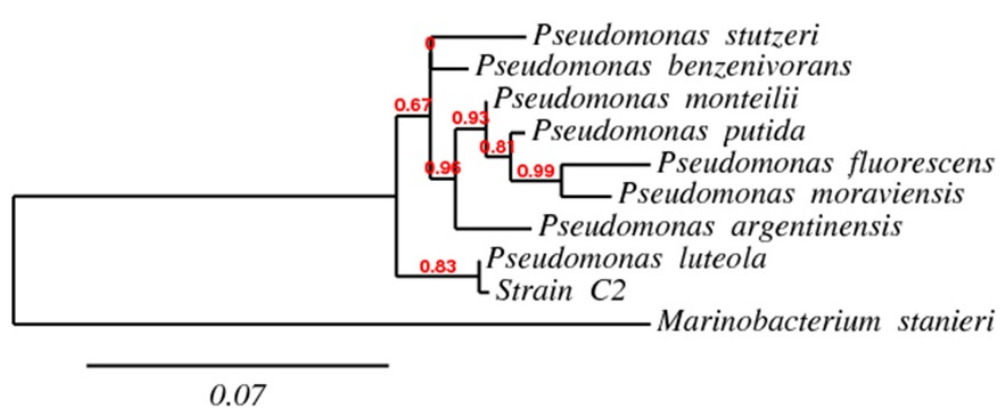

Figure 1 Phylogenetic dendrogram based on 1247 unambiguous bp of the 16S rRNA sequences indicating the position of Pseudomonas luteola strain C2 and its closest relative sequences validated at species level in the genus Pseudomonas.

not shown). In this work, the Box Behnken design (BBD) was used to study the effects of the three variables chosen towards their response and subsequently in the optimization study. Experiments according to the design were carried out and relevant results are shown in Table 2, which lists amylase activity. The mathematical equation given by the model is:

$$
\begin{gathered}
\text { Amylase activity }(\mathrm{U} / \mathrm{ml})=9.207-0.426 \mathrm{X}_{1}-0.598 \mathrm{X}_{2} \\
-1.389 \mathrm{X}_{3}-1.413 \mathrm{X}_{1}^{2}-1.761 \mathrm{X}_{2}^{2}-2.963 \mathrm{X}_{3}^{2} \\
+0.577 \mathrm{X}_{1} \mathrm{X}_{2}+1.255 \mathrm{X}_{1} \mathrm{X}_{3}+1.758 \mathrm{X}_{2} \mathrm{X}_{3}
\end{gathered}
$$

The results obtained are then analyzed by "F" statistical test for analysis of variance (ANOVA) to assess the "goodness of fit" (Table 5). The model equation adequately describes the response surfaces of Amylase activity in the interval of investigation. The model is found to be significant at 95\% confidence level by the F-test as shown in Table 5, with all $p$-values of regression $\leq 0.05$. With Pseudomonas luteola amylase activity as the response, the response surface (3D) and the contour plots (2D) of the quadratic model were shown in Figure 2. The obvious trough in the response surfaces indicates that the optimal conditions were exactly located inside the design boundary.

The surface graphs of response (amylase activity) showed a considerable curvature in contour curves, implying that these three factors were interdependent (Figure 2). There were significant interactive effects on amylase activity between temperature $\left({ }^{\circ} \mathrm{C}\right), \mathrm{pH}$ and incubation time (h). The contour plot of Temperature versus $\mathrm{pH}$ showed that the optimal conditions for the response were located in the region, where temperature ranged from 32 to $38^{\circ} \mathrm{C}$ and $\mathrm{pH}$ from 5.5 to 7.5 (Figure $2 \mathrm{C}$ ). The contour plots of incubation time versus $\mathrm{pH}$ or temperature showed that the optimal conditions for the response were obtained after 19-22 $\mathrm{h}$ of incubation and when $\mathrm{pH}$ and temperature ranged from 5.5 to 6.5 and from 33 to $37^{\circ} \mathrm{C}$, respectively (Figure 2A and 2B).

Under these conditions, the $\mathrm{C} 2$ amylase activity can reach $9.48 \mathrm{U} / \mathrm{ml}$. Similar results were obtained with Lactobacillus pentosus N3 and Lactobacillus plantarum Bom 816 when amylase activity ranged from $3-4$ to $21 \mathrm{U} / \mathrm{ml}$ and from 0.5 to $11.5 \mathrm{U} / \mathrm{ml}$, respectively [40].

\section{Conclusion}

A strain isolated from a sample of soil was selected for its ability to produce amylase. This isolate was identified by $16 \mathrm{~S}$ rRNA gene sequences analysis as $P$. luteola. Amylase optimization extraction was carried out using Box Behnken Design (BBD). The effect of three really influencing variables: temperature $\left({ }^{\circ} \mathrm{C}\right), \mathrm{pH}$ and incubation time (h) on amylase activity was investigated. Its maximal activity was in the $\mathrm{pH}$ and temperature ranged from 5.5 to 6.5 and from 33 to $37^{\circ} \mathrm{C}$, respectively. Under these conditions, the $\mathrm{C} 2$ amylase activity can reach 9.48 $\mathrm{U} / \mathrm{ml}$. The cloning and expression of its amylase is

\begin{tabular}{|c|c|c|c|c|c|c|}
\hline Source of variation & Sum of square (SS) & Degree of freedom (ddl) & Average square & Fisher number & Signification & $\overline{\mathrm{R}^{2}}$ \\
\hline Regression & 85.2004 & 9 & 9.4667 & 155.3619 & $0.641^{* *}$ & 0.93 \\
\hline Residues & 6.4013 & 5 & 1.2803 & - & - & - \\
\hline
\end{tabular}
under current investigation.

Table 5 Statistical parameters obtained from the ANOVA test performed for the model

**p-value $<0.01$. 
A)

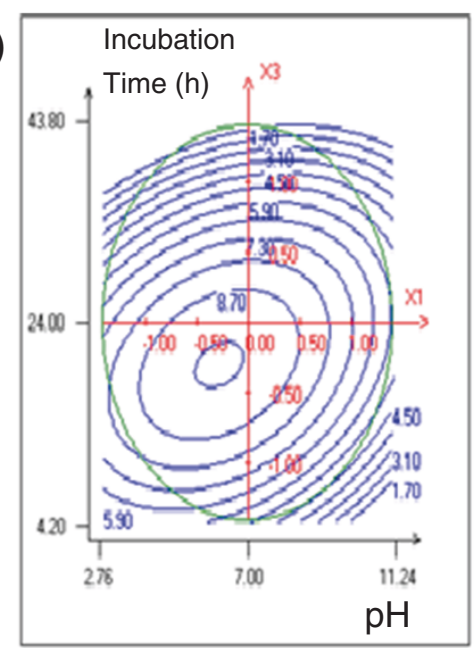

B)

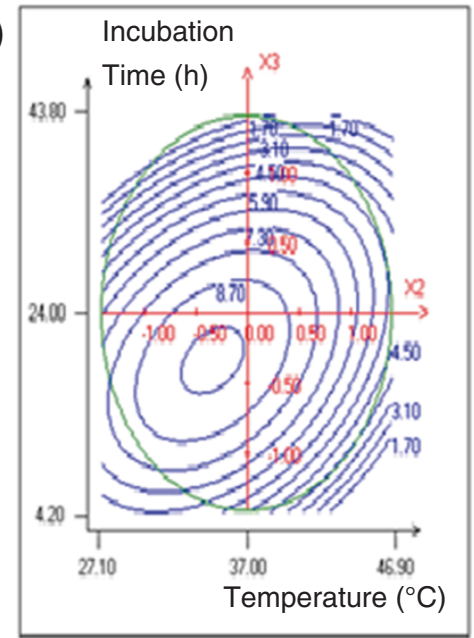

C)

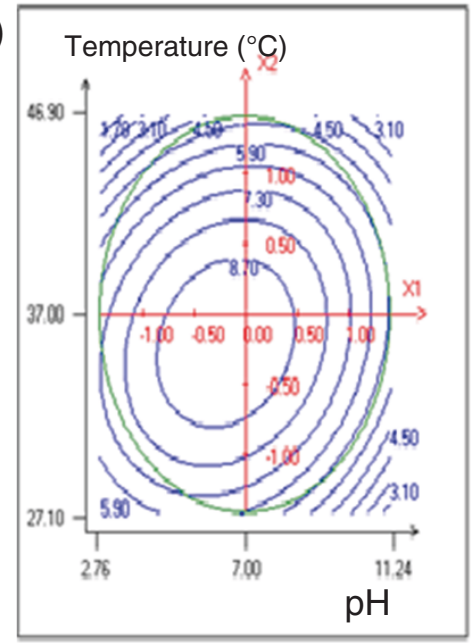

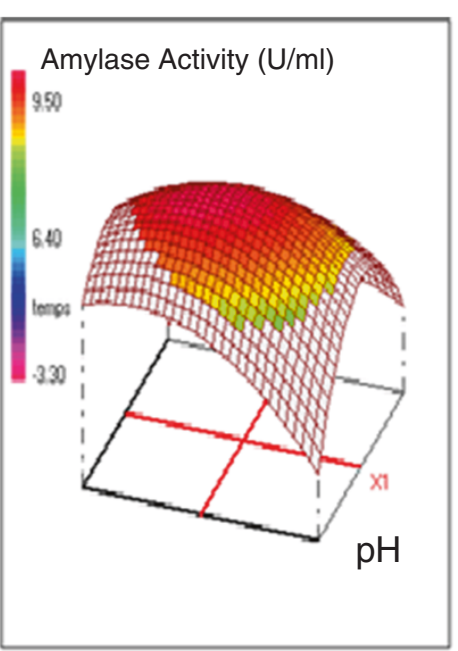
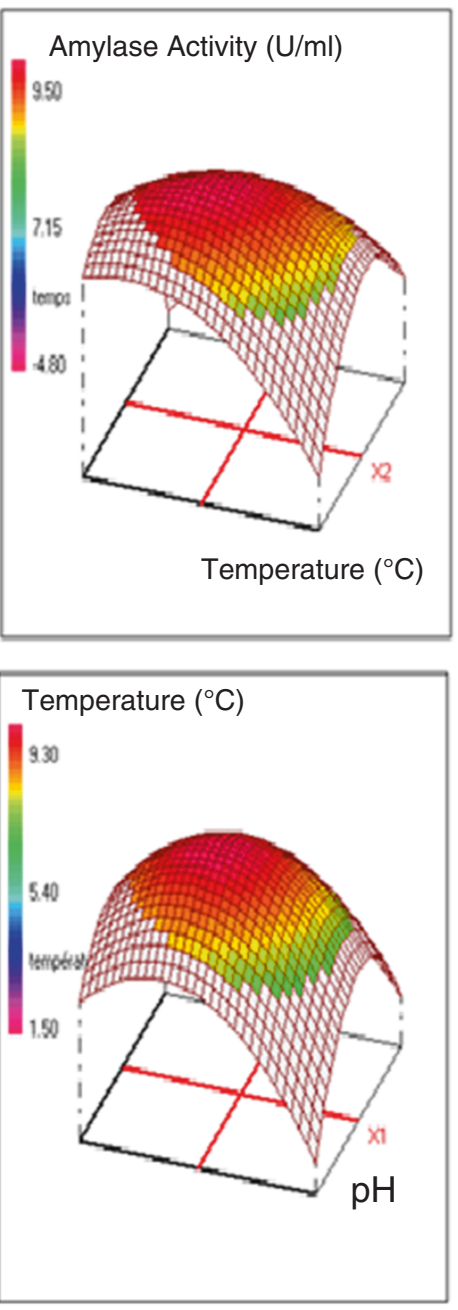

Figure 2 Surface graphs of response $Y$ (amylase activity $\mathrm{U} / \mathrm{ml}$ ) showing the effects of variables: $A$, effect of the incubation time versus $\mathrm{pH} ; \mathrm{B}$, effect of the incubation time versus temperature; $\mathrm{C}$, effect of the temperature versus $\mathrm{pH}$. 


\section{Competing interests}

The authors declare that they have no competing interests.

\section{Authors' contributions}

LK, MJ, NC, MD, RM and MB performed the experiments. LK, NG and IF designed the experiments, analyzed the data and conceived research. LK drafted the manuscript. LK, NG and IF have approved the final version of the manuscript. All authors read and approve the final manuscript.

\section{Acknowledgments}

The authors are grateful to Engineer Nihed Ben Halima for fruitful discussions and for her help. The authors would like to express their gratitude to Professor Radhouane Gdoura for his help.

\section{Author details}

${ }^{1}$ Faculté des Sciences de Sfax, Unité de recherche Toxicologie- Microbiologie Environnementale et Santé, Université de, Sfax, Tunisia. 'Laboratoire de Biotechnologie des Plantes, Faculté des Sciences de Sfax, Université de Sfax, Sfax, Tunisia. ${ }^{3}$ Département de génie biologique, Ecole Nationale d'Ingénieurs de Sfax, Université de Sfax, Sfax, Tunisia.

Received: 23 August 2013 Accepted: 28 December 2013

Published: 9 January 2014

\section{References}

1. Ikeda-Ohtsubo W, Miyahara M, Kim SW, Yamada T, Matsuoka M, Watanabe A, Fushinobu S, Wakagi T, Shoun H, Miyauchi K, Endo G: Bioaugmentation of a wastewater bioreactor system with the nitrous oxide-reducing denitrifier Pseudomonas stutzeri. J Biosci Bioeng 2013, 115:37-42.

2. Fendri I, Chaari A, Dhouib A, Jlassi B, Abousalham A, Carriere F, Sayadi S, Abdelkafi S: Isolation, identification and characterization of a new lipolytic Pseudomonas sp., from Tunisian soil. Environ Technol 2010, 31:87-95.

3. Fendri I, Bouaziz M, Labat M, Sayadi S, Abdelkafi S: Olive fermentation wastewater: the valorisation methods. Environ Technol 2013, 34:181-193.

4. Dabboussi F, Hamze M, Singer ER, Geoffroy V, Meyer JM, Izard D: Pseudomonas mosselii sp. nov., a novel species isolated from clinical specimens. Int J Syst Evol Microbiol 2002, 52:363-376.

5. Liu N, Jiang JL, Cai LL, Li W: Characterization and optimization of Fe(II)Cit-NO reduction by Pseudomonas sp. Environ Technol 2011, 32:1947-1953.

6. Liu J, Zhang Z, Zhu H, Dang H, Lu J, Cui Z: Isolation and characterization of a-amylase from marine Pseudomonas sp, K6-28-040. Afr J Biotechnol 2011, 10:2733-2740.

7. Khemakhem B, Fendri I, Dahech I, Belghuith K, Kammoun R, Mejdoub H: Purification and characterization of a maltogenic amylase from Fenugreek (Trigonella foenum graecum) seeds using the Box Behnken Design (BBD). Ind Crops Prod 2013, 43:334-339.

8. Ueda M, Asano T, Nakazawa M, Miyatake K, Inouye K: Purification and characterization of novel raw-starch-digesting and cold-adapted aamylases from Eisenia foetida. Comp Biochem Phys 2008, 150:125-130.

9. Fendri I, Ben Saad R, Khemakhem B, Ben Halima N, Gdoura R, Abdelkafi S: Effect of treated and untreated domestic wastewater on seed germination, seedling growth and amylase and lipase activities in Avena sativa L. J Sci Food Agric 2013, 93:1568-1574.

10. Pandey A, Nigam P, Soccol CR, Soccol VT, Singh D, Mohan R: Advances in microbial amylases. Biotechnol Appl Biochem 2000, 31:135-152.

11. Wang J, Wan W: Experimental design methods for fermentative hydrogen production: a review. Int J Hydrogen Energy 2009, 34:235-244.

12. Myer RH, Montogomery DC: Response surface methodology: process and product optimization using designed experiment. 2nd edition. New York: John Wiley and Sons; 2002.

13. Bae S, Shoda M: Statistical optimization of culture conditions for bacterial cellulose production using Box Behnken design. Biotechnol Bioeng 2005, 90:20-28.

14. Ray S, Reaume SJ, Lalman JA: Developing a statistical model to predict hydrogen production by a mixed anaerobic mesophilic culture. Int J Hydrogen Energy 2010:5332-5342.

15. Abdelkafi S, Labat M, Ben Ali Gam Z, Lorquin J, Casalot L, Sayadi S: Optimized conditions for the synthesis of vanillic acid under hypersaline conditions by Halomonas elongata DSM $2581^{\top}$ resting cells. World J Microbiol Biotechnol 2008, 24:675-680.
16. Abdelkafi S, Chamkha M, Casalot L, Sayadi S, Labat M: Isolation and characterization of a novel Bacillus sp., strain YAS1, capable of transforming tyrosol under hypersaline conditions. FEMS Microbiol Lett 2005, 252:79-84.

17. Abdelkafi S, Labat M, Casalot L, Chamkha M, Sayadi S: Isolation and characterization of Halomonas sp. strain IMPC, a p-coumaric acidmetabolising bacterium that decarboxylates other cinnamic acids under hypersaline conditions. FEMS Microbiol Lett 2006, 255:108-114.

18. Ben Ali Gam Z, Abdelkafi S, Casalot L, Tholozan JL, Oueslati R, Labat M: Modicisalibacter tunisiensis gen. nov., sp. nov., an aerobic, moderately halophilic bacterium isolated from an oilfield-water injection sample, and emended description of the family Halomonadaceae. Int J Syst Evol Microbiol 2007, 57:2307-2313.

19. Ben Ali Gam Z, Oueslati R, Abdelkafi S, Casalot L, Tholozan JL, Labat M: Desulfovibrio tunisiensis sp. nov., a novel weakly halotolerant, sulfatereducing bacterium isolated from exhaust water of a Tunisian oil refinery. Int J Syst Evol Microbiol 2009, 59:1059-1063.

20. Logan NA, Berkeley RCW: Identification of Bacillus strains using the API system. J Gen Microbiol 1984, 130:1871-1882.

21. Winker S, Woese CR: A definition of the domains Archea, Bacteria and Eucarya in terms of small subunit ribosomal rRNA characteristics. Syst Appl Microbiol 1991, 13:161-165.

22. Hall TA: BioEdit: a user-friendly biological sequence alignement editor and analysis program for windows 95/98 NT. Nucleic Acids Sym Ser 1999, 41:95-98.

23. Maidak BL, Cole JR, Lilbrum TG, Parker CT, Saxman PR Jr, Farris RJ, Garrity GM, Olsen GJ, Schmidt TM, Tiedje JM: The RDP-II (Ribosomal Database Project). Nucleic Acids Res 2001, 29:173-174.

24. Altschul SF, Madden TL, Schäffer AA, Zhang Z, Miller W, Lipman DJ: Gapped Blast and PSI-BLAST: a new generation of protein database search programs. Nucleic Acids Res 1997, 25:3389-3402.

25. Benson DA, Boguski MS, Lipman DJ, Oullette BFF, Rapp BA, Wheeler DL: GenBank. Nucleic Acids Res 1999, 27:12-17.

26. Jukes TH, Cantor CR: Evolution of protein molecules. In Mammalian Protein Metabolism. Edited by Munro HN. New York: Academic Press; 1969:211-232.

27. Saitou N, Nei M: The neighbor-joining method: a new method for reconstructing phylogenetic trees. Mol Biol Evol 1987, 4:406-425.

28. Felsenstein J: Confidence limits on phylogenies: an approach using the bootstrap. Evolution 1985, 39:783-791.

29. Abdelkafi S, Ogata H, Barouh N, Fouquet B, Lebrun R, Pina M, Scheirlinckx F, Villeneuve $P$, Carriere F: Identification and biochemical characterization of a GDSL-motif carboxylester hydrolase from Carica papaya latex. Biochim Biophys Acta 2009, 1791:1037-1046.

30. Barouh N, Abdelkafi S, Fouquet B, Pina M, Scheirlinckx F, Carrière F, Villeneuve P: Neutral lipid characterization of non-water-soluble fractions of Carica Papaya latex. J Am Oil Chem Soc 2010, 87:987-995.

31. Abdelkafi S, Barouh N, Fouquet B, Fendri I, Pina M, Scheirlinckx F, Villeneuve $P$, Carriere F: Further biochemical characterization of the lipase activity in Carica papaya latex. Plant Foods Hum Nutr 2011, 66:34-40.

32. Miller GL: Use of dinitrosalicylic acid reagent for determination of reducing sugars. Anal Chem 1959, 31:426-428.

33. Mathieu D, Nony J, Phan-Than-Luu R: NEMROD-W Software. Marseille: LPRAl; 2000.

34. Lai QL, Shao ZZ: Pseudomonas xiamenensis sp nov., a denitrifying bacterium isolated from activated sludge. Int I Syst Evol Microbiol 2008, 58:1911-1915.

35. Kato J, Kim HE, Takiguchi N, Kuroda A, Ohtake H: Pseudomonas aeruginosa as a model microorganism for investigation of chemotactic behaviors in ecosystem. J Biosci Bioeng 2008, 106:1-7.

36. Verhille S, Baïda N, Dabboussi F, Hamze M, Izard D, Leclerc H: Pseudomonas gessardii sp. nov. and Pseudomonas migulae sp. nov., two new species isolated from natural mineral waters. Int J Syst Bacteriol 1999, 49:1559-1572.

37. Vela Al, Gutiérrez MC, Falsen E, Rollán E, Simarro I, García P, Domínguez L, Ventosa A, Fernández-Garayzábal J: Pseudomonas simiae sp. nov., isolated from clinical specimens from monkeys (Callithrix geoffroyi). Int J Syst Evol Microbiol 2006, 56:2671-2676.

38. Lee SY, Rhee JS: Hydrolysis of triglyceride by the whole cell of Pseudomonas putida 3SK in two-phase batch and continuous reactors systems. Biotechnol Bioeng 2008, 44:437-443. 
39. Yang J, Zhang B, Yan Y: Cloning and expression of Pseudomonas fluorescens 26-2 lipase gene in Pichia pastoris and characterizing for transestérification. Appl Biochem Biotechnol 2009, 159:255-365.

40. Petrova P, Emanuilova M, Petrov K: Amylolytic Lactobacillus strains from Bulgarian fermented beverage boza. Z Naturforsch C 2010, 65:218-224.

doi:10.1186/1476-511X-13-9

Cite this article as: Khannous et al:: Isolation of a novel amylase and

lipase-producing Pseudomonas luteola strain: study of amylase

production conditions. Lipids in Health and Disease 2014 13:9.

\section{Submit your next manuscript to BioMed Central} and take full advantage of:

- Convenient online submission

- Thorough peer review

- No space constraints or color figure charges

- Immediate publication on acceptance

- Inclusion in PubMed, CAS, Scopus and Google Scholar

- Research which is freely available for redistribution 